\title{
MENGEMBANGKAN INTELIGENSI DAN KREATIVITAS ANAK USIA DINI
}

\author{
Oleh: M. Zaqin *) \\ zaqin_m@yahoo.co.id
}

\begin{abstract}
There are two reasons why intellegence and creativity of pre school children need to be developed? First of all, it is related to the development and the growth of children. Secondly, it is related to the demand of society development. Learning has important role in developing intellegence and creativity of pre school children. Learning which is considered able to develop intellegence and creativity and to develop children's right and left brain is the learning suitable to the principle of pre school children education. Centre is one of the ways to manage class whose teaching-learning process consists of related and integrated centres based on fully and appropriately need of children. Centre can be developed by institution in accordance with the competence of educators, staffs of education and the facilities. In general, there are at least four centres Pre school (PAUD) institutions must develop. They are; Balok centre, role play (main peran) centre, natural things (bahan alam) centre and preparation centre.
\end{abstract}

Keywords: Intelligence, Creativity, pre schoolChildren 


\section{A. PENDAHULUAN}

Undang-Undang Nomor 20 Tahun 2003 tentang sistem Pendidikan Nasional Pasal 1 ayat (4) menjelaskan bahwa pendidikan anak usia dini adalah upaya pembinaan yang ditujukan kepada anak sejak lahir sampai dengan usia 6 tahun yang dilakukan melalui pemberian rangsangan untuk membantu pertumbuhan dan perkembangan jasmani dan rohani agar anak memiliki kesiapan dalam memasuki pendidikan lebih lanjut. Untuk mencapai apa yang diamanatkan perundangan di atas, anak usia dini perlu mendapatkan stimulasi secara tepat dan akurat dalam mengembangkan aspek jasmani dan rohani, material dan spiritual, dan intelgensi dan kretivitasnya. Kesalahan dalam memberi stimulasi tentu akan berdampak tidak baik terhadapa perkembangan kedua aspek tersebut. Salah satu dampak yang tidak baik itu adalah anak hanya akan berkembang dalam satu aspek saja. Berkembangnya satu aspek itu juga berpengaruh terhadap berkembangnya satu belahan otak saja, yaitu belahan otak kiri. Sementara belahan otak kanan terabaikan, sehingga tidak dapat berkembang secara selaras.

Kenyataan di dunia pendidikan, hampir semua guru dalam menstimulasi pertumbuhan dan perkembangan anak terjebak dalam pengembangan aspek jasmani, material, dan inteligensi. Sementara aspek rohani, spiritual, emosional, dan kreativitas terabaikan. Goleman (dalam Karmani, 2005:1) mengatakan bahwa faktor-faktor dalam menciptakan bintang-bintang kinerja di perusahaan atau institusi ternyata $20 \%$ ditentukan oleh inteligensi (IQ), dan $80 \%$ oleh EQ. 


\section{B. PEMBAHASAN}

\section{Inteligensi dan Kreativitas}

\section{a. Inteligensi}

Inteligensi merupakan suatu kata yang memiliki makna abstrak. Tidak seperti kata tinggi, berat, umur. Meski tampak abstrak, banyak ahli psikologi yang mencoba mengembangkan teorinya dalam memahami inteligensi. Paling tidak ada dua pandangan yang berkembang dalam memahami inteligensi, yaitu ahli yang memandang intelgensi sebagai faktor tunggal dan pandangan yang menyatakan inteligensi sebagai faktor multiple. Ahli psikologi yang mengembangkan pandangannya terhadap inteleigensi sebagai faktor tunggal adalah Jensen, Ebbinghaus, Terman, serta Stein dan Book. Jensen (1979) mengartikan inteligensi sebagai kemampuan mental umum (general mental ability). Ebbinghaus, sebagaimana dalam Wahab (1998) menyatakan bahwa inteligensi sebagai kemampuan untuk membuat kombinasi. Sementara Terman, sebagaimana dalam Wahab (1998) mengemukakan bahwa inteligensi adalah kemampuan untuk berpikir abstrak. Sedangkan Stein dan Book (2002) mengungkapkan bahwa inteligensi adalah ukuran kemampuan intelektual, analisis, logika, dan rasio seseorang.

Sedangkan ahli psikologi yang memandang inteligensi sebagai faktor multiple antara lain Kail dan Pallegreno (Wahab, 1998), Robert Stenberg (1982), dan Gadner (2002). Dari ketiga tokoh ini yang paling populair adalah Gadner yang telah menggambarkan inteligensi ke dalam berbagai bentuk, yaitu kemampuan di bidang linguistik, logika matematik, musik, keruangan, kinestetik-motorik, interpersonal, dan intrapersonal. 


\section{b. Kreativitas}

Bentukan kata kreativitas, sebagaimana dalam Kamus Besar Bahasa Indonesia (2001) diartikan sebagai 1) kemampuan untuk mencipta; daya cipta, 2) perihal berkreasi; kekreatifan. Sementara Ghallagher (dalam Rachmawati, 2010) memberi batasan bahwa kreativitas suatu proses mental yang dilakukan individu berupa gagasan maupun produk baru, atau mengombinasikan antara keduanya yang pada akhirnya akan melekat pada dirinya. Lebih lanjut Supriadi sebagaimana dalam Rachmawati (2010) mengutarakan bahwa kreativitas adalah kemampuan seseorang untuk melahirkan sesuatu yang baru, baik berupa gagasan maupun karya nyata yang relative berbeda dengan apa yang telah ada. Adapun Semiawan (1997) mengemukakan bahwa kreativitas merupakan kemampuan untuk memberikan gagasan baru dan menerapkannya dalam pemecahan masalah. Ahli lain yang memberi batasan tentang kreativitas adalah Chaplin sebagaimana dalam Rachmawati (2010), kreativitas diartikan sebagai kemampuan menghasilkan bentuk baru dalam seni, atau dalam permesinan, atau dalam memecahkan masalah-masalah dengan metode-metode baru.

Dari pendapat para ahli di atas, tampak yang berbeda hanya dari segi redaksioanalnya saja, tetapi dari segi isi (content) hampir semua ahli sepakat bahwa kreativitas merupakan proses mental individu yang melahirkan gagasan, proses, metode ataupun produk baru yang efektif bersifat imajinatif, estetis, fleksibel, integrasi, suksesi, diskontinuitas, dan diferensiasi yang berdaya guna dalam berbagai bidang untuk pemecahan suatu masalah. 


\section{Perlunya Inteligensi dan Kreativitas Anak Usia Dini Dikembangkan}

Ada dua alasan, mengapa inteligensi dan kreativitas anak usia dini perlu dikembangkan? Pertama, berkaitan dengan perkembangan dan pertumbuhan anak. Kedua, berkaitan dengan tuntutan perkembangan masyarakat (Semiawan, 2008). Kedua alasan tersebut akan diuraikan sebagai berikut.

\section{a. Tuntutan Perkembangan dan Pertumbuhan Anak}

Carol Gestwicki (1995) sebagaimana dalam Sumantri (2005) mengemukakan beberapa prinsip dasar perkembangan.

1) Dalam perkembangan terdapat urutan yang dapat diramalkan. Pemahaman tentang perilaku yang seharusnya terjadi berikunya, akan membantu para praktisi untuk mengenal perkembangan yang khusus dan menantang fase perkembangan berikutnya yang semestinya.

2) Perkembangan pada suatu tahap merupakan landasan bagi perkembangan berikutnya. Suatu perkembangan tidak akan mungkin terjadi berkesinambungan dengan baik bila anak didorong untuk melampaui atau secara tergesa-gesa menjalani tahap-tahap awal. Anak harus diberi waktu sesuai yang mereka butuhkan sebelum berlanjut pada tahap berikutnya.

3) Dalam perkembangan terdapat waktu-waktu yang optimal. Waktu-waktu yang menunjukkan kesiapan harus dikenali melalui pengamatan yang cermat. Proses pembelajarana kan terjadi dengan mudah pada saat yang optimal. Setiap pengajaran tidak akan menjadikan proses belajar dengan mudah sebelum mencapai kesiapan.

4) Perkembangan merupakan hasil interaksi faktor-faktor biologis (kematangan) dan faktor-faktor lingkungan (belajar). Kematangan 
merupakan prasyarat munculnya kesiapan untuk belajar. Lingkungan menentukan arah perkembangan.

5) Perkembangan maju berkelanjutan merupakan kesatuan yang saling berhbungan, dengan semua aspek-aspek (fisik, kognitif, emosional, sosial) yang saling memengaruhi. Semua pengalaman belajar sebagai peluangpeluang yang terintegrasi untuk pertumbuhan, dan bukan merupakan keterampilan yang terpisah-pisah.

6) Setiap individu berkembang sesuai dengan waktunya masing-masing. Suatu hal yang tidak mungkin jika membandingkan individu-individu ditinjau dari umurnya. Setiap anak mempunyai kebutuhan dan karakteristik yang unik pada tahap tertentu. Hal ini memungkinkan terjadinya perbedaan dan pilihan-pilihan.

7) Perkembangan berlangsung dari yang sederhana kepada yang kompleks, dari yang umum kepada yang khusus. Dengan memperhatikan prinsip ini, tidak mngkin anak melampaui tahap tertentu atau terburu pada perilaku tertentu bila mereka belum siap.

Sementara Sutterly dan Donely (dalam Sumantri, 2005) dalam penelitiannya mengenai proses pertumbuhan menghasilkan sepuluh prinsip dasar pertumbuhan. Beberapa prinsip tersebut akan diuraikan sebagai berikut:

1) Pertumbuhan adalah kompleks dan semua aspek-aspeknya berhubungan sangat erat. Sebagai contoh kompleksnya pertumbuhan ialah anak yang gagal untuk tumbuh karena kurangnya curahan kasih sayang dari ibunya. Hal ini menjelaskan, bahwa faktor emosional merupakan bagian yang integral dari proses pertumbuhan.

2) Pertumbuhan mencakup hal-hal yang bersifat kuantitatif dan kualitatif. 44

Secara kuantitatif, pertumbuhan ditandai dengan anak tumbuh secara 
berangsur baik tinggi maupun berat badannya. Sedangkan pertumbuhan secara kualitatif, ditandai dengan semakin berfungsinya bagian-bagian organ tubuh pada anak

3) Pertumbuhan adalah proses yang berkesinambungan dan terjadi secara teratur. Semua dimensi pertumbuhan terjadi secara teratur dan dalam urutan yang dapat diramalkan. Walaupun prosesnya terjadi secara teratur, namun hasilnya tidak seragam. Karena pertumbuhan merupakan proses yang berkesinambungan dan teratur, maka pola pertumbuhan dapat dikenali pada setiap anak. Setiap anak yang normal, bergerak melalui tahap-tahap yang sama dengan karakteristik yang manusiawi. Tahap-tahap ini dihubungkan aspek-aspek pertumbuhan seperti pengukuran fisik, perkembangan organ-organ, dan kematangan fungsi perilaku.urutan perkembangan seperti ini juga tejadi pada perkembangan kognitif, sosial, emosional, dan kreativitas anak.

4) Pada pertumbuhan dan perkembangan terdapat keteraturan arah. Keteraturan dalam pertumbuhan dan perkembangan ini terjadi misalnya, pada awal pertumbuhan bayi manusia, yang pesat terdapat bagian badan, sedangkan pada masa kanak-kanak pertumbuhan yang pesat pada bagian kaki. Demikian juga keteraturan pada pertumbuhan dan perkembangan organ-organ tubuh berikut fungsinya.

5) Tempo pertumbuhan setiap anak tidak sama. pada setiap anak terdapat variasi umur dalam mencapai jenjang-jenjang pertumbuhan karena kecepatan menjalani kehidupan antara seorang dan lainnya berbeda, walaupun setiap orang melalui jalan yang sama. Anak, berkembang secara berkelanjutan sejak masa konsepsi, mengalami interupsi pada masa kelahiran dan kehilangan berat badan, secara berangsur bertumbuh 
ukuran/besar dan beratnya. Tempo pertumbuhan anak tidak dapat ditentukan hanya dengan melihat berat dan besarnya badan. Tetapi, ukuran dan kriteria yang baik tentang pertumbuhan adalah sistem rangka tubuh. Rangka tubuh tumbuh mengikuti rencana perkembangan secara genetik yang terkontrol dan digunakan sebagai indeks kecepatan pertumbuhan organism. Dalam menggunakan setiap ukuran tentang pertumbuhan akan terdapat variasi pada anak-anak yang seusia. Setiap anak secara individual mempunyai pola pertumbuhan sendiri-sendiri. Meskipun pertumbuhan sama dengan anak lain, waktu terjadinya pertumbuhan akan sangat individual.

6) Aspek-aspek yang berada dari pertumbuhan berkembang pada waktu dan kecepatan yang bebeda. Sebagai contoh, kepala bayi yang baru lahir lebih besar jika disbanding dengan ukuran badan lainnya. Hal ini menunjukkan bahwa pertumbuhan kepala lebih pesat pada masa sebelum lahir. Dalam tahun pertama pada saat pertumbuhan, tulang belakang mendominasi, anak menjadi tampak bulat dan gemuk. Pada saat anak mulai belajar berjalan, kepala dan badannya yang masih berat menyebabkan anak kelihatan pendek. Setelah tahun pertama, kakinya tumbuh lebih cepat dari pada bagian tubuh yang lain. Pada masa ini pula, lemak yang ada dalam tubuh anak mulai berkurang dan bahkan menghilang, sehingga penampilan anak prasekolah tampak kecil dan oarng jawa mengatakan ndawani.

7) Kecepatan dan pola pertumbuhan dapat dimodifikasi oleh faktor-faktor intrinsik dan ekstrinsik. Faktor yang paling jelas mempengaruhi adalah nutrisi. Selain memengaruhi kecepatan pertumbuhan, nutrisi juga mempercepat kedewasaan. Pertumbuhan, kesehatan dan kemampuan mental dapat pula dipengaruhu nutrisi awal. 
8) Pada pertumbuhan dan perkembangan terdapat masa-masa kritis. Masa kritis itu terjadi pada 45 bulan pertama, karena pada masa itu pertumbuhan otak sangat pesat dan banyak ahli yang mengatakan sebagai usia keemasan. Oleh sebab itu, pada masa-masa tersebut anak harus mendapat stimulasi yang baik dan benar dalam mengembangkan kemampuan otaknya, baik otak belahan kiri maupun otak belahan kanan.

9) Pada suatu organisme ada kecendrungan untuk mencapai potensi perkembangan yang optimal baik dalam struktur maupun fungsinya. Meskipun potensi pertumbuhan seseorang banyak dipengaruhi oleh faktor genetik, pertumbuhan anak secara nyata dipengaruhi pula kondisi lingkungan. Lingkungan yang kondusif tidak menjamin individu menambah potensi genetiknya, tetapi hanya dapat memaksimalkan potensinya.

10) Setiap individu tumbuh dengan caranya sendiri yang unik. Individu dalam menjalani hidupnya dilengkapi dengan pembawaan yang unik serta pengalaman yang bersifat pribadi yang dilalui dengan kecepatannya sendiri. Keunikan ini menyebabkan setiap anak memiliki pengalaman yang tidak sama dalam proses perkemangannya.

Secara alamiah perkembangan dan pertumbuhan anak itu berbeda-beda, baik dalam intelgensi, bakat, minat, kreativitas, kematangan emosi, kepribadian, keadaan jasmani dan keadaan sosialnya. Perbedaan perkembangan ini secara jelas selama proses pembelajaran di dalam kelas. Bagi guru yang berkompetensi paedagogik, akan dapat dengan mudah melihat perbedaan antara anak yang dengan cepat menerima materi pembelajaran dan ada yang relativ lambat. Dalam proses pembelajaran pula akan dapat dilihat perbedaan bakat anak. Bakat (aptitude), sebagaimana dalam Semiawan (2008) 
dirumuskan sebagai potensi kemampuan yang dibawa sejak lahir. Lebih lanjut Semiawan (2008) menjelaskan, bahwa banyak faktor yang dapat memengaruhi perkembangan bakat ini dan banyak pula yang dapat dilakukan oleh lingkungan (sekolah) dalam pengembangan intelgensi dan kreativitas anak usia dini.

Menurut Crak (1986), Kitano (1986), Gowan (1976), Koestler (1983), Lipman, dan Siler (1990) sebagaimana dalam Semiawan (2008) dikatakan bahwa, melatih anak dengan berbagai faktor sejak dini, bearti mendidik anak menjadi anak berbakat. Lebih lanjut dikatakan bahwa ekspresi tertinggi keberbakatan adalah kreativitasnya. Prespektif orang berbakat, menurut Semiawan (2008) bertolak dari asumsi bahwa secara genetis kelompok ini telah dianugrahi bakat luar biasa. Oleh sebab itu, diharapkan sumbangan kemampuan, pikiran dan tenaga yang besar bagi pengembangan bakat anak. Lingkungan berkewajiban mengembangkannya. Oleh karena itu dibutuhkan program pendidikan dan pembelajaran yang mampu mengembangkan intelgensi dan kreativitas anak usia dini.

\section{b. Tuntutan Perkembangan Masyarakat}

Semakin pesatnya perkembangan ilmu pengetahuan dan teknologi, maka di masa mendatang semakin tajam pula persaingan antarbangsa. Hanya bangsa dan negara yang memiliki keunggulan teknologi yang akan mampu bertahan dan menjadi pemenang dalam kompetisi itu. Bagi Negara tertinggal yang tidak mengoptimalkan sumber daya manusia jelas ia akan menajdi konsumen teknologi negara-negara maju. Dampak yang lebih parah lagi bagi sumber daya manusia (SDM) yang tidak berkualitas di era industrialisasi seperti ini adalah hanya sebagai penonton dan tamu dalam negerinya sendiri. Ia 48 
tidak mampu bersaing dengan SDM yang memang dipersiapkan bisa hidup di era kompetitif ini. Ke depan, SDM yang banyak dicari adalah sumber daya yang "bisa" bukan sekedar "tahu". Sebagaimana dikatakan Prof. Rhenald Kasali (Jawa Post, 13 Desember 2016) bahwa kaum muda harus berubah dari sekadar "tahu" menjadi "bisa" mewujudkan gagasannya.

Dalam konteks inilah prespektif pendidikan dan pembelajaran mulai dari anak usia dini sampai ke perguruan tinggi harus diubah. Pembelajaran, seharusnya bukan hanya menyiapkan peserta didik menguasai (tahu) teori, tetapi harus mampu mengantarkan menjadi terampil (bisa) mengaplikasikan teori di dalam dunia kerja.

\section{Prespektif Pembelajaran Berkualitas}

Salah satu indikator pembelajaran berkualitas adalah proses pembelajaran yang mampu mengembangkan secara seimbang belahan otak kiri dan otak kanan secara serasi. Pentingnya menyeimbangkan belahan otak kiri dan kanan diakibatkan oleh fungsi yang berbeda. Muhammad, (2010) mengatakan bahwa belahan otak kiri berkaitan dengan fungsi akademik yang terdiri atas kemampuan berbicara, mengolah tata bahasa, baca tulis, daya ingat, logika, angka, analisis, dan lain-lain. Sementara belahan otak kanan sebagai tempat untuk mengembangkan hal-hal yang bersifat artistik, kreativitas, perasaan emosi, gaya bahasa, irama musik, imajinasi, khayalan, warna, pengenalan diri, orang lain, sosialisasi, serta pengembangan kepribadian.

Sementara Yus (2011: 46) mengatakan bahwa belajar paling efektif bagi anak usia dini adalah melalui pendekatan konkret dan berorientasi pada bermain. Namun kenyataan menunjukkan, banyak pendidik yang terjebak dalam pembelajaran yang hanya berorientasi pada keterampilan akademik dan 
mengabaikan kegiatan bermain sebagaimana tuntutan perkembangan belajar anak. Pembelajaran yang dianggap mampu mengembangkan inteligensi dan kreativitas serta mengembangkan belahan otak kiri dan otak kanan bagi anak usia dini adalah pembelajaran yang sesuai dengan prinsip-prinsip pembelajaran PAUD.

\section{a. Prinsip-prinsip pembelajaran PAUD}

Tim Kualita Pendidikan Indonesia (KPI) dan BPPAUDNI Regional II dalam bukunya Mengenal Sentra dan Lingkungan (2012) mengatakan bahwa, untuk mengembangkan potensi anak usia dini terdapat sepuluh prinsip pembelajaran yang diterapkan. Kesepuluh prinsip itu akan diuraikan berikut:

1) Belajar melalui bermain

Dunia anak adalah dunia bermain. Oleh sebab itu, bermain merupakan cara yang paling baik uttuk mengembangkan kemampuan anak yang sesuai dengan perkembangannya. Melalui bermain, anak memeroleh dan memroses informasi serta melatih keterampilan yang dibutuhkan. Tahap bermain disesuaikan dengan perkembangan anak dan difokuskan pada permainan yang menyenangkan serta meningkatkan kreativitas anak.

2) Pembelajaran berorientasi pada perkembangan anak

Anak mengalami pertumbuhan fisik dan perkembangan mental yang unik dan berbeda dengan yang lain. Oleh sebab itu, pendidik harus mampu mengembangkan pembelajaran yang sesuai dengan karakteristik dan tingkat perkembangan anak.

3) Pembelajaran berorientasi pada kebutuhan anak 
Anak usia dini membutuhkan stimulasi untuk membantu pertumbuhan fisik dan perkembangan psikis secara optimal. Karena itu, pembelajaran anak usia dini harus dirancang untuk memenuhi kebutuhan tersebut.

4) Pembelajaran berpusat pada anak

Pembelajaran di anak usia dini hendaknya menempatkan anak sebagai subjek pendidikan, sehingga seluruh kegiatan pembelajaran diarahkan atau berpusat pada anak. Dalam pembelajaran yang berpusat pada anak, anak diberi kesempatan menentukan pilihan, mengemukakan pendapat, dan aktif melakukan atau mengalami. Tugas pendidik adalah sebagai pembimbing atau fasilitator.

5) Pembelajaran menggunakan pendekatan tematik Fungsi tema dalam pendekatan tematik adalah sebagai wadah untuk mengenalkan berbagai konsep kepada anak, menyatukan isi kurikulum dalam satu kesatuan yang utuh, memperkaya perbendaharaan kata anak, dan menjadikan pembelajaran lebih bermakna. Tema dipilih berdasarkan prinsip kedekatan, kesederhanaan, daya tarik, dan keinsidentilan. Namun, ika pendidk mengalami kesulitan dalam menghubungkan indikator atau capaian hasil belajar dengan tema, yang lebih diutamakan adalah indikator atau capaian hasil belajar, bukan tema.

6) Kegiatan pembelajaran yang PAKEM.

Pembelajaran di PAUD hendaknya aktif, kreatif, efektif, dan menyenangkan. Pendidik harus mampu menciptakan dan mengondisikan kegiatan yang menarik, membangkitkan rasa ingin tahu anak, mampu memotivasi anak untuk berpikir kritis dan kreatif dalam suasana yang menyenangkan. 
7) Pembelajaran mengembangkan kecakapan hidup Pembelajaran di PAUD diarahkan untuk mengembangkan kecakapan hidup anak. Pengembangan kecakapan hidup dilakukan secara terpadu, baik melalui pembiasaan maupun pengembangan kemampuan dasar yang berguna bagi kelangsungan hidup anak.

8) Pembelajaran didukung oleh lingkungan yang kondusif. Lingkungan pembelajaran harus diciptakan sedemkian rupa agar nyaman dan menyenangkan. Secara fisik, ligkungan tempat belajar ditata dengan memperhatikan keamanan dan kenyamanan anak dalam bermain. Penataan ruang kelas disesuaikan dengan ruang gerak anak dalam bermain agar anak dapat berinteraksi secara optimal dengan pendidik dan anak yang lain sehingga suasana belajar yang demokratis dapat dibangun. Pendidik dan anak sama-sama menciptakan suasana belajar yang akomodatif dan terbuka. Pendidik hendaknya selalu memberi kesempatan kepada anak untuk aktif memberikan reaksi dan memberikan pendapat tanpa takut.

9) Pembelajaran yang bermakna.

Pembelajaran bermakna merupakan suatu proses pembelajaran yang efektif dan membawa pengaruh perubahan terhadap tingkah laku anak didik berupa hasil belajar yang mencakup ranah afektif, psikomotorik, dan kognitif. Pembelajaran akan bermakna jika anak terlibat secara aktif dalam pembelajaran yang memungkinkan anak memperoleh pengalaman baru yang bermanfaat bagi kehidupannya.

10) Pembelajaran dilakukan secara bertahap dan berulang-ulang.

Ada dua alasan mengapa pembelajaran harus dilakukan secara bertap dan berulang-ulang. Yang pertama terkait dengan pertumbuhan anak bertambah secara bertahap. Yang kedua, terkait dengan perkembangan 
kerja otak yang semakin lama semakin kompleks. Oleh karena itu pembelajarna harus dilakukan secara bertahap sesuai dengan perkembangan anak dan harus dilakukan secara berulang-ulang agar anak mampu membangun pengetahunnya dengan baik.

Untuk dapat melaksanakan prinsip-prinsip di atas, diperlukan model pengelolaan kelas dalam pembelajaran yang sesuai. Warner dan Lynch (2004) mengatakan bahwa lingkungan kelas memengaruhi anak. Bila kelas hangat dan mengundang anak-anak untuk datang dan belajar, maka anak akan merespons sesuai keadaan. Model pengelolaan kelas yang sesuai dan dimungkinkan untuk dilaksanakan adalah model sentra.

\section{b. Model Sentra}

Setiawaty (2006) memaparkan, bahwa sentra merupakan salah satu cara pengelolaan kelas yang kegiatan proses pembelajarannya terdiri atas sentra-sentra yang saling terkait dan terpadu berlandaskan kebutuhan anak secara utuh dan patut. Sistem sentra ini dikembangkan sesuai dengan pemikiran dasar Jean Piaget (dalam Setiawaty, 2006) yang mengatakan bahwa anak-anak harus dapat melakukan percobaan sendiri dan melakukan penelitian sendiri. Pendidik tentnya dapat mengarahkan mereka dengan menyediakan alat-alat yang tepat. Tetapi yang paling mendasar adalah agar anak dapat mengerti tentang sesuatu, anak harus membangun dirinya dan menemukan dirinya. Sentra dapat dikembankan oleh lembaga sesuai dengan kemampuan pendidik, tenaga kependidikan, dan sarana prasarana. Oleh karena itu, setiap lembaga Paud tidaklah sama dalam menyediakan sentra. Hal terpenting yang harus diperhatiakan pengelola PAUD sebagaimana dikatakan Welkart, Rodgers, dan Adcock (dalam Setiawaty, 2006) adalah bahwa sentra yang 
disediakan harus dapat memenuhi tiga jenis permainan. Ketiga jenis permainan itu adalah sensorimotor, bermain peran, dan bermain pembangunan. Paling tidak, ada empat sentra yang harus dikembangkan lembaga PAUD. Keempat sentra itu antara lain sentra balok, sentra main peran, sentra bahan alam, dan sentra persiapan.

1) Sentra balok

Lazimnya, sentra balok ini berisi balok-balok berbagai ukuran dan warna, logo, lotto sejenis, lotto berpasangan, kepingan geometri, kotak geometri, kendaraan tiruan (laut, udara, dan darat), rambu-rambu lalulintas, kubus berpola, kubus berbagai ukuran dan warna, korek apai, lidi, tusuk es krim, bola berbagai ukuran dan warna, dus bekas, dan sebagainya.

Ketika anak menggunakan bahan bermain di atas, berarti ia sedang mengembangkan kemampuan sensorimotor, representasi, atau kecerdasan merefleksi. Bermain balok memberikan kesempatan bagi anak untuk mengembangkan 1) keterampilan hubungan dengan teman sebaya, 2) kemampuan berkomunikasi, 3) kekuatan koordinasi motorik halus dan kasar, 4) konsep matematika dan geometri, 5) pemikiran simbolik, 6) pengetahuan pemetaan, dan 7) keterampilan membedakan penglihatan.

2) Sentra bermain peran

Alat yang harus ada dalam sentra bermain peran ini antara lain, tempat tidur anak (boneka), lemari kecil, meja-kursi kecil, boneka, tempat jemuran, tempat setrikaan, baju-baju besar, handuk, bekas make up, minyak wangi, sisir, kompor-komporan, alat memasak-memasakan, tas, sepatu, sandal, telepon mainan, baju profesi (polisi, tentara, dokter, dll).

Kegiatan yang dapat dilakukan di sentra ini adalah bermain peran. Bermain peran disebut juga bermain simbolik, pura-pura, fantasi, 
imajinasi, atau main drama. Vigotzky dan Erikson (dalam Setiawaty, 2006) mengatakan bahwa bermain drama sangat penting untuk perkembangan kognitif/inteligensi, sosial, dan emosional anak usia dini (36 tahun).

Sentra bermain peran akan memberi manfaat untuk 1) mengembangkan kreativitas dan partumbuhan inteligensi atau intelektual anak, 2) membantu anak untuk menghubungkan dunia nyata dan imajinasi, 3) meningkatkan kemampuan berbahasa, 4) membiasakan anak untuk mematuhi aturan yang berlaku, 5) membantu penyesuaian diri anak, dan 6) memperoleh kesenangan dari bermain yang dilakukan.

3) Sentra bahan alam

Kegiatan bermain ang menggunakan bahan bermain seperti cat, krayayon, spidol, palydough, air, pasir, sabun, dan sebagainya dikandung maksud untuk mengembangkan sensorimotor anak pada saat anak diberi kesempatan bermain dengan bermacam-macam bahan dan alat permainan, baik dalam maupun di luar ruangan, kemampuan sensorimotornya akan semakin terlatih.

4) Sentra persiapan

Sentra persiapan, sesuai dengan namanya, ditujukan pada ranah perkembangan kognitif dan motorik halus anak. Kegiatan yang banyak diberikan pada sentra ini adalah persiapan keaksaraan, motorik halus, serta koordinasi mata dan tangan untuk mempersiapkan kematangan anak sehingga siap untuk membaca dan menulis.

Pengalaman bermain keaksaraan yang bisa dilakukan di sentra persiapan antara lain 1) mengelompokkan benda-benda berdasarkan warna, bentuk, dan ukuran, 2) menyusun huruf menjadi kata dengan kartu kata, 3) 
mencontoh huruf, kata, kalimat pendek dengan menggunakan pensil, spidol, atau krayon, 4) menyusun kata/kalimat dengan kartu kata atau stempel huruf, 5) menyalin kata dengan computer, 6) bermain papan pasak, 7) membuat pola kubus, 8) mencari dan menggunting huruf dan angka.

\section{PENUTUP}

Usia dini (3-6 tahun) disebut sebagai usia keemasan. Disebut usia keemasan, karena pada rentang usia tersebut perkembangan dan pertumbuhan mental anak menjadi dasar perkembangan dan pertumbuhan berikutnya. Pada rentang itulah saat yang tepat untuk menyetimulasi dan mengeksplorasi potensi yang ada dalam diri anak. Stimulasi dan eksplorasi potensi anak, terutama untuk pengembangan inteligensi dan kreativitas anak merupakan suatu keniscayaan untuk mempersiapkan anak bisa dan bertahan hidup di zamannya. Stimlasi dan eksplorasi yang dilakukan pendidik harus tetap dalam koridor yang tepat, yaitu sesuai dengan irama dan tempo perkembangan anak. Tidak dengan cara instan, karena anak bukan lah orang dewasa dalam bentuk mini.

\section{DAFTAR PUSTAKA}

Departemen Agama. 2005. Pedoman Pelaksanaan Kurikulum Raudlatul Athfal. Jakarta: Dirjend. Kelembagaan Agama Islam.

Karmani. 2005. Mengembangkan Kecerdasan Majemuk. Makalah disajikan dalam seminar IGTKI Kabupaten Tuban.

Kasali, Rhenald. 13 Desember, 2016. Job on Demand. Jawa Pos, hlm. 11. 
Muhammad, As'adi. 2010. Bila Otak Kanan dan Otak Kiri Seimbang. Jogjakarta: Diva Press.

Musfiroh, Tadkiroatun. 2015. Bermain dan Permainan Anak. Jakarta: Penerbit Universitas Terbuka.

Pusat Bahasa Departemen Pendidikan Nasional. 2001. Kamus Besar Bahasa Indonesia. Jakarta: Balai Pustaka

Rachmawati, Yeni. 2010. Strategi Pengembangan Kreativitas pada Anak Usia TK. Jakarta: Kencana Prenada Media Group.

Semiawan, Conny. R. 2008. Belajar dan Pembelajaran Prasekolah dan Sekolah Dasar. Jakarta: PT. Macanan Jaya cemerlang.

Sumantri, Mulyani. 2005. Perkembangan Peserta Didik. Jakarta: Pusat Penerbitan UT.

Stiawaty, Dessi. 2006. Perkembangan Anak dan Pendidikannya. Surabaya: Konsorsium Pendidikan Islam.

Tim KPI dan BPPAUDNI Reg. II. 2012. Mengenal Sentra dan Lingkaran. Surabaya: Pustaka BPPAUDNI.

Undang-undang RI Nomor 20 Tahun 2003 Tentang Sistem Pendidikan Nasional. Jakarta: PT. Agenda Utama.

Wahab, Abdul. 1998. Isu Linguistik Pengajaran Bahasa dan Sastra. Surabaya: Airlangga University Press.

Warner, Laverne. 2006. Mengelola Kelas Prasekolah. (penerjemah: Widyananto Sutanto). Jakarta: Penerbit Erlangga.

Yus, Anita. 2011. Model Pendidikan Anak Usia Dini. Jakarta: Kencana Prenada Media Group. 